\title{
PENGARUH FASILITAS PAJAK DAN UKURAN PERUSAHAAN TERHADAP MANAJEMEN PAJAK YANG TERDAFTAR DI BEI 2017-2020
}

\begin{abstract}
Penulis: Abstrak: Penelitian ini bertujuan untuk mengetahui dan menganalisis Asri Indah Sari Marbun ${ }^{1}$ Paul E. Sudjiman ${ }^{2}$

Afiliasi: Universitas Advent Indonesia $^{1}$

Korespondensi: asriindahsarim@gmail. com

Histori Naskah: apakah terdapat pengaruh fasilitas pajak dan ukuran perusahaan terhadap manajemen pajak yang terdaftar di Bursa Efek Indonesia. Penelitian ini merupakan penelitian kuantitatif dengan data sekunder yang diperoleh. Dengan data yang diperoleh dari laporan keuangan 10 perusahaan manufaktur pada subsektor tekstil dan garmen tahun 2017-2020. Data yang digunakan dalam penelitian ini menggunakan fasilitas perpajakan dan ukuran perusahaan. Penulis mengolah data menggunakan SPSS dengan melakukan uji statistik deskriptif, uji multikolinearitas, uji normalitas, uji autokorelasi, uji determinasi, uji t dan uji F. Hasil penelitian ini menunjukkan bahwa fasilitas perpajakan tidak berpengaruh signifikan terhadap pengelolaan pajak dan ukuran perusahaan berpengaruh signifikan terhadap pengelolaan pajak. pada perusahaan manufaktur di subsektor tekstil dan garmen.
\end{abstract} Submit: 99-00-9999 Accepted: 99-00-9999 Published: 99-00-9999

Kata kunci: Fasilitas Pajak, Manajemen Pajak, Ukuran Perusahaan

\section{Pendahuluan}

Manajemen pajak diperlukan sebagai sarana untuk memenuhi kewajiban perpajakan dengan benar, dan meminimalkan risiko pajak tanpa melanggar peraturan perpajakan yang berlaku, sehingga perusahaan dapat memaksimalkan seluruh potensi bisnis yang ada untuk mencapai laba dan likuiditas sesuai dengan tujuan perusahaan.

Adanya kepentingan yang bertolak belakang dari pemerintah sebagai pengena pajak dan perusahaan sebagai sisi yang dikenai pajak, pemerintah sebisa mungkin memperoleh pajak sebanyak mungkin dari masing-masing perusahaan, kebalikan dari pemerintah justru dari sisi perusahaan sebisa mungkin membayar pajak lebih sesedikit untuk memperoleh laba semaksimal mungkin. Sinaga dan Sukartha (2018) mengatakan bahwa adanya kepentingan yang bertolak belakang dari pemerintah dan 


\section{- 1 - Jurnal Audit \& Perpajakan}

Volume : 1 | Nomor 1 | November 2021 | E-ISSN : 2809-1809. | DOI: 10.47709/jap.v1n1.1203

perusahaan, akan memungkinkan perusahaan dalam melakukan pengelolaan pajak untuk meminimalkan jumlah pajak dibayar.

Di Indonesia, sektor industri tekstil dan garmen menjadi tulang punggung di sektor manufaktur dalam tahun terakhir belakangan ini. Kontribusi yang signifikan pada pertumbuhan ekonomi Indonesia tercipta dari industri tekstil dan garmen karena mampu membuka banyak lowongan kerja dan juga menumbuhkan tingkat investasi dalam dan luar negeri.

Dilansir dari cbnindonesia.com (2019) sebuah artikel yang menceritakan bahwa di Indonesia masih menjadi salah satu masalah yang memberatkan pelaku industri. Ketua Umum Asosiasi Pertekstilan Indonesia (API), Ade Sudrajat Usman selaku perwakilan Pengusaha Tekstil mengungkapkan keluh kesahnya di hadapan Jokowi mengenai Peraturan Menteri Perdagangan (Permendag) Peraturan No. 64 Tahun 2017 tentang Ketentuan Bea Masuk Tekstil dan Produk Tekstil. Menurutnya, selama ini regulasi perpajakan di sektor properti seringkali membuat pelaku usaha secara psikologis terkekang dan tidak mampu berkembang. Hal ini, dinilai memberatkan.

Perusahaan dapat meningkatkan efisiensi perpajakan melalui manajemen pajak, misalnya dengan cara mengalihkan jumlah pajak yang dibayar ke tahun berikutnya sekaligus mengurangi pembayaran pajak kepada pemerintah semaksimal mungkin.

Manajemen pajak merupakan total pajak sebenarnya yang dibayar perusahaan dan terdaftar dalam laporan laba rugi yang dimiliki perusahaan. Pengelola perusahaan bertanggungjawab untuk menggunakan sumber daya yang dimiliki perusahaan dengan efektif untuk meningkatkan nilai perusahaan dan menjaga kinerja perusahaan itu sendiri.

Beberapa faktor yang mampu memaksimalkan pengelolaan pajak perusahaan yaitu tax facilitation. Di dalam undang-undang pasal 17 ayat (2b) No. 36 Thn 2008 dikatakan bahwa pihak pemerintah memberi penurunan jumlah pajak senilai 5\% pada perusahaan yang menjual $>=40 \%$ sahamnya di Bursa Efek Indonesia.

Faktor lain yang memengaruhi manajemen pajak ialah ukuran perusahaan. Susilowati (2018) menuliskan ukuran perusahaan merupakan pengukuran yang diklasifikasikan berdasarkan besar atau kecilnya ukuran perusahaan dan besarnya pendapatan yang didapatkan oleh suatu perusahaan. Perusahaan berukuran besar akan membayarkan tarif pajak lebih sedikit dibandingkan perusahaan berukuran kecil 
\. • P Jurnal Audit \& Perpajakan

Volume : 1 | Nomor 1 | November 2021 | E-ISSN : 2809-1809. | DOI: 10.47709/jap.v1n1.1203

karena perusahaan berukuran besar memiliki sumber daya guna melakukan pengelolaan pajak. Jika perusahaan tidak optimal dalam melakukan manajemen pajak maka perusahaan akan kehilangan peluang memperoleh insentif pajak, dimana insentif pajak mampu memperkecil jumlah pajak yang dibayarkan. Penelitian Minah (2017) membuktikan jika besar dan kecilnya suatu perusahaan memiliki pengaruh positif signifikan terhadap manajemen pajak. Hasil berbeda menurut Komang (2016) yakni, bahwa ukuran perusahan berpengaruh negatif signifikan terhadap manajemen pajak.

Berdasarkan latar belakang uraian dan kasus di atas maka penulis tertarik untuk melakukan penelitian yang berjudul "Pengaruh Fasilitas Perpajakan dan Ukuran Perusahaan Terhadap Manajemen Pajak Yang Terdaftar di BEI 2017-2020”.

Idetifikasi Masalah

a. Adakah pengaruh Fasilitas Perpajakan terhadap Manajemen Pajak yang terdaftar di BEI 2017$2020 ?$

b. Adakah pengaruh Ukuran Perusahaan terhadap Manajemen Pajak yang terdaftar di BEI 2017$2020 ?$

c. Adakah pengaruh Fasilitas Perpajakan dan Ukuran Perusahaan terhadap Manajemen Pajak yang terdaftar di BEI 2017-2020?

\section{Studi Literatur}

\section{Fasilitas Pajak}

Fasilitas perpajakan yang terdapat pada UU pasal 17 ayat (2b) nomor 36 Thn 2008 menjelaskan mengenai perusahaan yang memiliki kriteria sesuai dengan ketentuan akan memperoleh fasilitas berbentuk pengurangan jumlah pajak senilai 5\%. Adanya pengurangan jumlah pajak senilai $5 \%$ akan memperkecil tarif pajak terutang yang akan dibayarkan perusahaan. Perusahaan yang terkena tarif lebih kecil akan melakukan manajemen pajak untuk tetap menaati peraturan perpajakan sehingga tidak akan dikenai sanksi yang akan merugikan perusahaan (Pohan, 2011). 
\. • P Jurnal Audit \& Perpajakan

Volume : 1 | Nomor 1 | November 2021 | E-ISSN : 2809-1809. | DOI: 10.47709/jap.v1n1.1203

\section{Ukuran Perusahaan}

Ukuran perusahaan adalah suatu pengelompokkan dari besar kecilnya ukuran suatu perusahaan. Metode pengklasifikasian ukuran perusahaan, terlihat dari banyaknya jumlah asset yang dipunya perusahaan. Asset dianggap memiliki tingkat yang lebih stabil dibandingkan aset yang lain dan cenderung berkesinambungan dari setiap periodenya. Setiap perusahaan yang tidak optimal dalam melakukan manajemen pajak maka perusahaan itu bisa kehilangan peluang untuk memperoleh insentif pajak, dimana insentif pajak mampu memperkecil jumlah pajak yang dibayarkan. Penelitian yang dilakukan Minah (2017) menunjukkan bahwa ukuran perusahaan memiliki pengaruh positif signifikan terhadap manajemen pajak. Hasil yang berbeda menurut Komang (2016) yakni bahwa ukuran perusahan memiliki pengaruh negatif signifikansi terhadap manajemen pajak. Penelitian yang dilakukan Muhardi (2015) menuliskan ukuran perusahaan diukur dengan rumus Log total aset.

\section{Manajemen Pajak}

Manajemen pajak merupakan sarana untuk memenuhi kewajiban perpajakan dengan baik, namun untuk memperoleh laba dan likuiditas yang diharapkan perusahaan, pembayaran pajak dapat diminimalkan. Oleh karena itu, Menurut Fatimah (2020) manajemen pajak adalah suatu metode yang dapat dilakukan bagian manajemen perusahaan untuk menghemat tarif pajak yang dibayarkan sesuai dengan peraturan hukum yang berlaku. Pengukuran manajemen pajak dalam penelitian ini menggunakan rumus effective tax rate.

\section{Pengaruh Fasilitas Perpajakan terhadap Manajemen Pajak}

Dari perspektif teori keagenan, ketika perusahaan tidak menerima insentif pajak sesuai dengan ketentuan pemerintah, maka manager dari perusahaan akan berusaha mendapatkan celah yang ada pada peraturan perpajakan untuk mengurangi beban pajak. Perusahaan yang dikenai jumlah pajak lebih kecil akan melakukan manajemen pajak guna memastikan kepatuhan terhadap peraturan perpajakan sehingga perusahaan dapat terhindar dari kerugian. Dari pernyataan tersebut sehingga terbentuklah hipotesis

H1: Fasilitas pajak memiliki pengaruh signifikan terhadap manajemen pajak 
\. • P Jurnal Audit \& Perpajakan

Volume : 1 | Nomor 1 | November 2021 | E-ISSN : 2809-1809. | DOI: 10.47709/jap.v1n1.1203

\section{Pengaruh Ukuran Perusahaan terhadap Manajemen Pajak}

Menurut Arjana dan Saputra (2017) ukuran perusahaan yang besar akan memudahkan perusahaan untuk memasuki pasar modal, sehingga dapat menggunakan kesempatan ini untuk mendapatkan dividen yang tinggi. Berkaitan dengan sumber daya, perusahaan dengan ukuran besar tentunya akan memiliki lebih banyak sumber daya yang bisa dimanfaatkan. Menurut Darmawan dan Sukartha (2014) perusahaan berskala besar akan memiliki sumber daya yang berlimpah untuk memaksimalkan kinerjanya. Perusahaan berukuran besar membayarkan pajak lebih sedikit dibandingkan perusahaan berukuran kecil karena perusahaan besar mempunyai sumber daya melimpah. Jika perusahaan tidak optimal dalam melakukan manajemen pajak maka perusahaan bisa kehilangan peluang untuk memperoleh insentif pajak, dimana insentif pajak mampu memperkecil jumlah pajak yang dibayarkan. Berdasarkan uraian tersebut maka terbentuk hipotesis

H2: Ukuran perusahaan memiliki pengaruh signifikan terhadap manajemen pajak

\section{Pengaruh Fasilitas Perpajakan dan Ukuran Perusahaan terhadap Manajemen Pajak}

Adanya fasilitas pengurangan tarif pajak senilai 5\% akan mengurangkan tarif pajak yang dibayar oleh perusahaan. Perusahaan yang terkena tarif lebih kecil akan melakukan manajemen pajak untuk tetap menaati peraturan perpajakan sehingga tidak akan dikenai sanksi yang akan merugikan perusahaan (Pohan, 2011). Hasil penelitian ini didukung dengan penelitian yang telah dilakukan oleh Darmadi (2013) dan Imelia (2015), bahwa fasilitas pajak memiliki pengaruh terhadap manajemen pajak. Arjana dan Saputra (2017) ukuran perusahaan yang besar akan memudahkan perusahaan dalam memasuki pasar modal yang memiliki kesempatan besar mendapatkan dividen yang tinggi. Perusahaan besar cenderung memiliki aset yang besar. Aset tersebut dapat menjadi pengurang beban pajak perusahaan, khususnya aset tetap. Penelitian ini selaras dengan penelitian Sinaga and Sukartha (2018) bahwa ukuran perusahaan memiliki pengaruh terhadap manajemen pajak.

H3 : Fasilitas Pajak dan Ukuran Perusahaan memiliki pengaruh signifikan terhadap Manajemen Pajak 
\. • P Jurnal Audit \& Perpajakan

Volume : 1 | Nomor 1 | November 2021 | E-ISSN : 2809-1809. | DOI: 10.47709/jap.v1n1.1203

\section{Metode Penelitian}

Pada penelitian ini, penulis menggunakan data sekunder. Data sekunder yang dipakai pada penelitian ini, yaitu ukuran perusahaan yang diukur dihitung dengan rumus Log of Total Assets dan manajemen pajak diukur dengan menggunakan Efective Tax Rate. Penelitian ini menggunakan laporan keuangan perusahaan manufaktur subsektor tekstil dan garmen pada tahun 2017-2020 yang terdaftar di BEI.

\section{Populasi dan Sampel}

Populasi dalam penelitian ini ialah perusahaan manufaktur subsektor tekstil dan garmen pada tahun 2017-2020. Pemilihan sampel dilakukan dengan menggunakan metode purposive sampling.

No. Kriteria Sample umlah Sampel

srusahaan manufaktur subsektor tekstil dan garmen yang

21

rdaftar di Bursa Efek Indonesia periode 2017-2020

susahaan yang laporang keuangan kurang lengkap dan tidak

empunyai piutang pada pihak berelasi

stal perusahaan yang digunakan menjadi sampel

10

stal observasi (10x4)

40 
\. . D Jurnal Audit \& Perpajakan

Volume : 1 | Nomor 1 | November 2021 | E-ISSN : 2809-1809. | DOI: 10.47709/jap.v1n1.1203

\section{Hasil}

\section{Statistik Deskriptif}

Berdasar pada hasil dari analisis statistik deskriptif, didapatkan dalam tabel-tabel melalui beberapa hasil analisis deskriptif dengan setiap variabel yang mana hal ini terdiri dari variabel dependen yang merupakan manajemen pajak dan variabel independen dengan variabel perencanaan pajak. Yang mana hal ini di perlihatkan menggunakan karakteristik dari sampel yang dipakai didalam penelitian yang mencakup Sampel $(\mathrm{N})$, rata-rata (Mean) nilai maksimum serta minimum.

\section{Fasilitas Pajak}

Pada statistik deskriptif tersebut maka dapat dilihat pada tabel dibawah yang mana berisikan variabel fasilitas pajak:

\section{Descriptive Statistics}

\begin{tabular}{|r|r|r|r|r|}
\hline & $\begin{array}{r}\text { Minimu } \\
\mathrm{m}\end{array}$ & $\begin{array}{c}\text { Maximu } \\
\mathrm{m}\end{array}$ & Mean & Std. \\
& & & & \\
$\mathrm{T}$ & $\mathrm{T}$ & & & \\
$\mathrm{R}$ & 677182 & 2441134 & 16866556 & \\
$\mathrm{R}$ & 33075,0 & 27371,0 & 120,4333 & \\
$\mathrm{~V}$ & 0 & 0 & \\
$\mathrm{~V}$ & & & & \\
$\mathrm{a}$ & & & & \\
$\mathrm{i}$ & & & & \\
$\mathrm{d}$ & & & & \\
\hline
\end{tabular}


\. . D Jurnal Audit \& Perpajakan

Volume : 1 | Nomor 1 | November 2021 | E-ISSN : 2809-1809. | DOI: 10.47709/jap.v1n1.1203

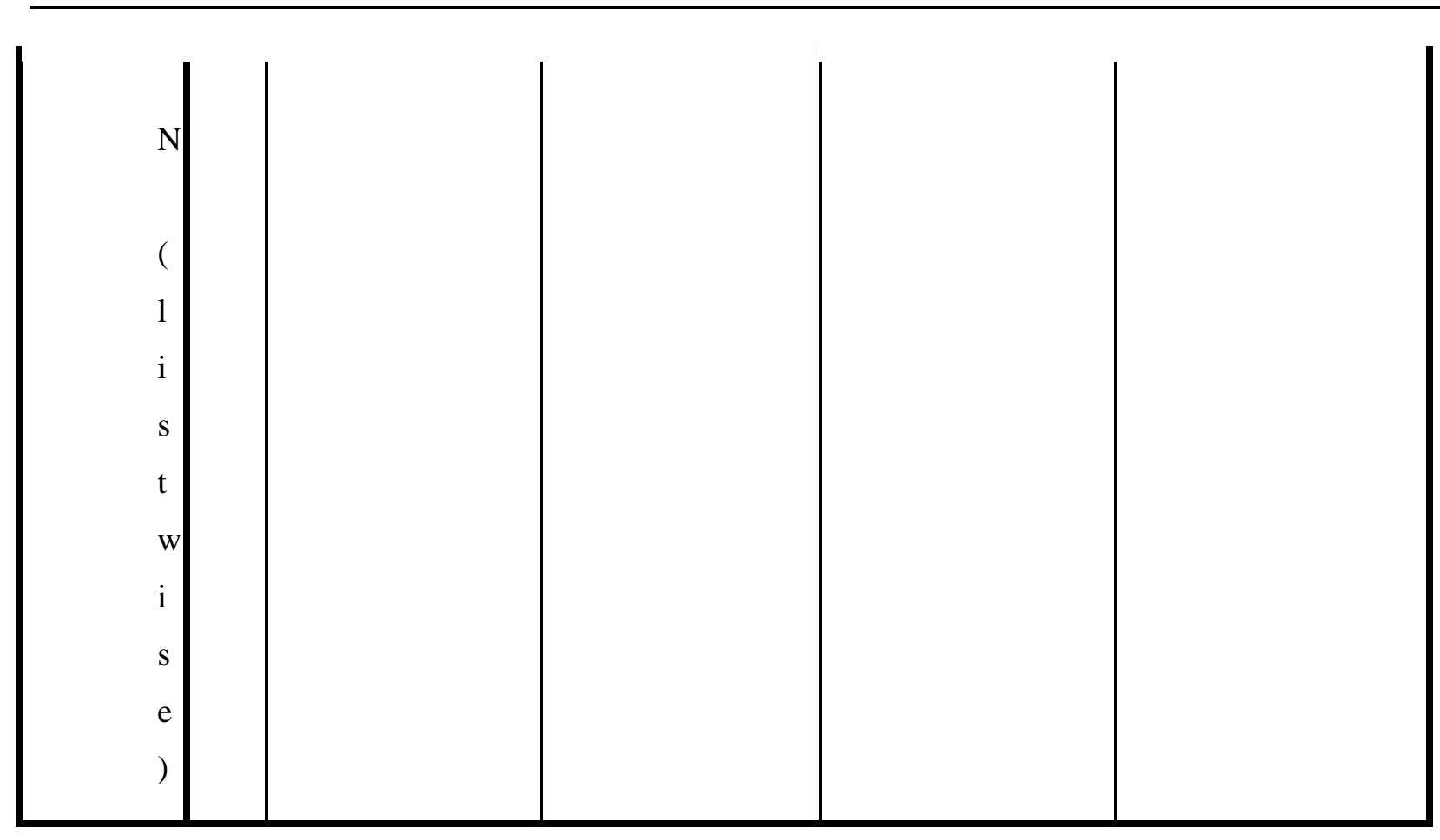

Jika melihat pada tabel diatas memperlihatkan jika sampel yang digunakan pada penelitian ini adalah sebanyak 30 data. Hasil yang diperoleh pada tabel tersebut mempunyai nilai minimum 677718233075,00, nilai maksimum sebesar 244113427371,00 selain itu juga memiliki mean sebesar 16866556120,433. Yang mana hasil tersebut memperlihatkan jika rata-rata dari sampel perencanaan pajak yang digunakan mempunyai nilai yang positif.

\section{Manajemen Pajak}

Selanjutnya deskriptif statistik dari variabel manajemen pajak diperoleh tabel sebagai berikut

\section{Descriptive Statistics}

\begin{tabular}{|l|r|r|r|r|r|}
\hline $\mathrm{N}$ & $\mathrm{M}$ & $\begin{array}{c}\text { Max } \\
\mathrm{imu}\end{array}$ & Mean & $\begin{array}{c}\text { Std. } \\
\text { Deviatio }\end{array}$ \\
\hline
\end{tabular}


- A • P Jurnal Audit \& Perpajakan

Volume : 1 | Nomor 1 | November 2021 | E-ISSN : 2809-1809. | DOI: 10.47709/jap.v1n1.1203

\begin{tabular}{|c|c|c|c|c|c|}
\hline & & $\begin{array}{l}\mathrm{i} \\
\mathrm{m} \\
\mathrm{u} \\
\mathrm{m}\end{array}$ & $\mathrm{m}$ & & $\mathrm{n}$ \\
\hline CTR & $\begin{array}{l}3 \\
0\end{array}$ & $\begin{array}{r}, 0 \\
1\end{array}$ & $\begin{array}{r}702 \\
098 \\
0,00\end{array}$ & $\begin{array}{r}118046 \\
4,6662\end{array}$ & $\begin{array}{r}2254952 \\
, 76817\end{array}$ \\
\hline SIZE & $\begin{array}{l}3 \\
0\end{array}$ & $\begin{array}{l}, 0 \\
6\end{array}$ & $\begin{array}{r}839 \\
05,0 \\
0\end{array}$ & $\begin{array}{r}10834, \\
5876\end{array}$ & $\begin{array}{r}23101,1 \\
0530\end{array}$ \\
\hline $\begin{array}{l}\text { FASPER } \\
\text { Valid N } \\
\text { (listwise) }\end{array}$ & $\begin{array}{l}3 \\
0 \\
3 \\
0\end{array}$ & $\begin{array}{r}, 0 \\
0\end{array}$ & 1,00 &, 8148 & ,39585 \\
\hline
\end{tabular}

Jika dilihat dari tabel diatas maka dapat di lihat jika penelitian ini menggukan 30 sampel. Dengan nilai minimun, maksimum dan mean dari CTR sebesar 0,01, 7020980,00 dan 1180464,6662. Sedangkan nilai minimun, maksimum dan mean dari SIZE adalah 0,06, 83905,00 dan 10834,5876. Sedangkan nilai minimun, maksimum dan mean dari FASPER adalah $0,00,1,00$ dan 0,8148 .

\section{Uji Normalitas}

One Sample Kolmogorov- Smirnov Test

\begin{tabular}{|l|l|l|l|}
\hline & CTR & SIZE & FASPER \\
\hline
\end{tabular}


\. • P Jurnal Audit \& Perpajakan

Volume : 1 | Nomor 1 | November 2021 | E-ISSN : 2809-1809. | DOI: 10.47709/jap.v1n1.1203

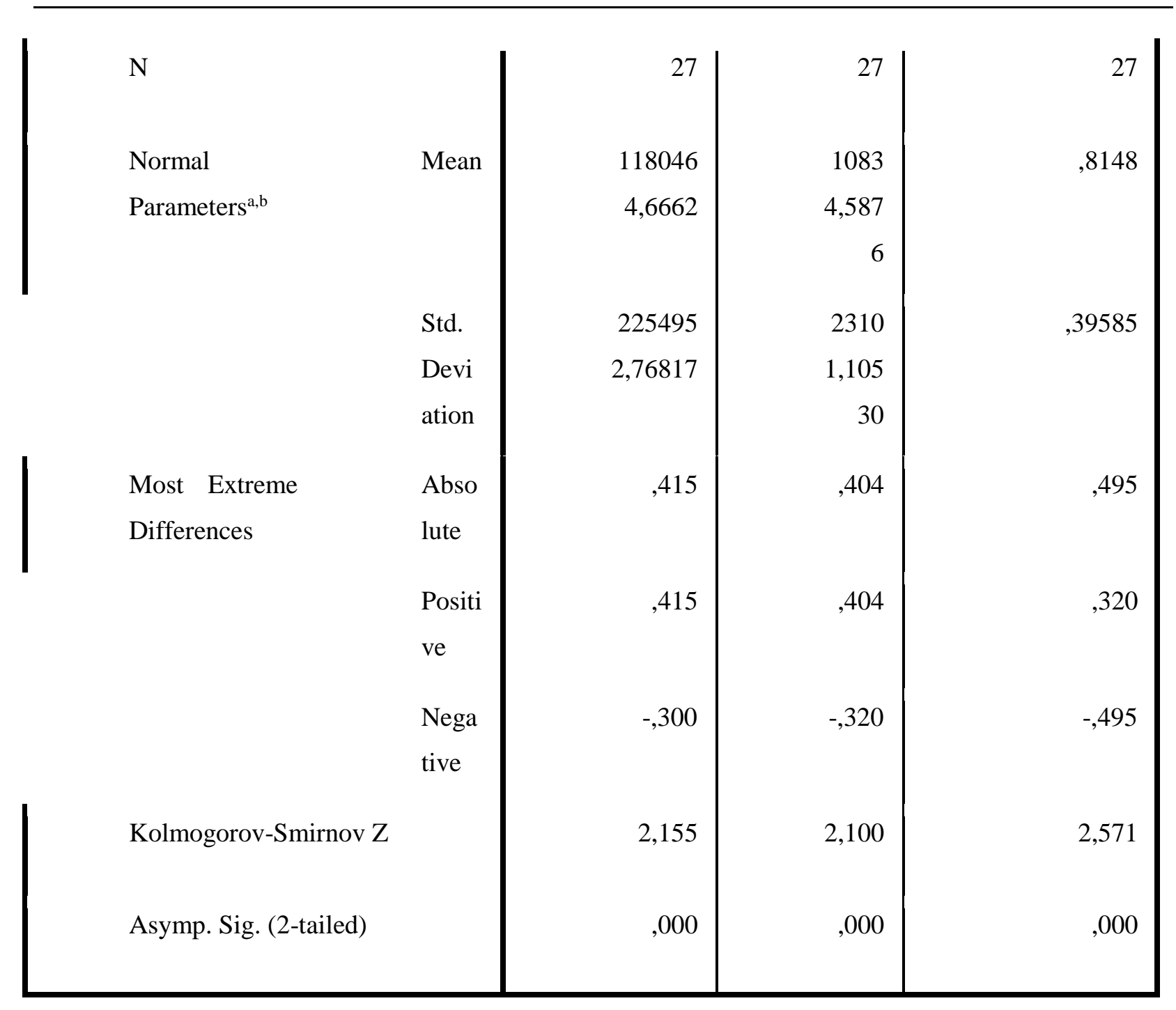

Berdasarkan hasil uji normalitas menggunakan One-Sample Kolmogorov-Smirnov Test diatas maka diperoleh hasil dari Kolmogorov-Smirnov senilai 0,000>0,05 dengan demikian data tersebut telah memenuhi syarat karena telah terdistribusi secara normal.

\section{Uji Multikolinearitas}




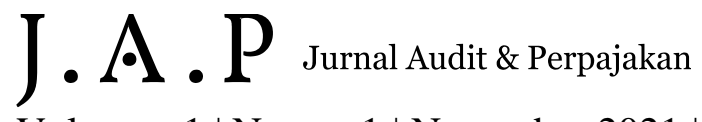

Volume : 1 | Nomor 1 | November 2021 | E-ISSN : 2809-1809. | DOI: 10.47709/jap.v1n1.1203

\section{Coefficients $^{a}$}

\begin{tabular}{|c|c|c|c|c|c|c|c|c|}
\hline & \multirow[t]{2}{*}{ Model } & \multicolumn{2}{|c|}{$\begin{array}{c}\text { Unstandardized } \\
\text { Coefficients }\end{array}$} & \multirow{2}{*}{$\begin{array}{c}\text { Standard } \\
\text { ized } \\
\text { Coefficie } \\
\text { nts } \\
\text { Beta }\end{array}$} & \multirow[t]{2}{*}{$\mathrm{T}$} & \multirow[t]{2}{*}{ Sig. } & \multicolumn{2}{|c|}{$\begin{array}{c}\text { Collinearity } \\
\text { Statistics }\end{array}$} \\
\hline & & B & $\begin{array}{l}\text { Std. } \\
\text { Error }\end{array}$ & & & & $\begin{array}{c}\text { Toleran } \\
\text { ce }\end{array}$ & VIF \\
\hline 1 & $\begin{array}{l}\text { (Const } \\
\text { ant) }\end{array}$ & $\begin{array}{r}278176,0 \\
01\end{array}$ & $\begin{array}{r}1049694 \\
097\end{array}$ & & $\begin{array}{r}, 26 \\
5\end{array}$ & $\begin{array}{r}, 79 \\
3\end{array}$ & & \\
\hline & SIZE & $-14,407$ & 19,200 &,- 148 & $\begin{array}{r}- \\
, 75 \\
0\end{array}$ & $\begin{array}{r}, 46 \\
0\end{array}$ & ,990 & $\begin{array}{r}1,01 \\
0\end{array}$ \\
\hline & FASPE & 1298927, & 1120510, & ,228 & 1,1 &, 25 & 990 & 1,01 \\
\hline & $\mathrm{R}$ & 218 & 725 & & 59 & 8 & & 0 \\
\hline
\end{tabular}

a. Dependent Variable: CTR

Kesimpulan yang didapatkan dari tabel diatas adalah ditemukannya tolerance dan VIF pada setiap variabel, yang mana sebagai berikut:

a. Tolerance yang diperoleh pada variabel SIZE yaitu $0,990>0,10$ dan VIF $1.010<10$. Hal ini mempunyai arti jika pada SIZE tidak terjadi multikolineartitas.

b. Tolerance yang diperoleh pada variabel FASPER yaitu 0,990 > 0,10 dan VIF $1.010<10$. Hal ini mempunyai arti jika pada FASPER tidak terjadi multikolineartitas.

\section{Uji Autokorelasi}


\. • P Jurnal Audit \& Perpajakan

Volume : 1 | Nomor 1 | November 2021 | E-ISSN : 2809-1809. | DOI: 10.47709/jap.v1n1.1203

Uji ini digunakan sebagai cara untuk dapat mengetahui korelasi yang terjadi antara residual dan juga pengamatan lainnya mada model regresi. Prasyaratan yang harus di lakukan sebelum melakukan uji ini adalah tidak adanya autokorelasi. Uji ini menggunakan model durbin watson untuk mengetahui ada tidaknya auto korelasi.

\section{Model Summary ${ }^{b}$}

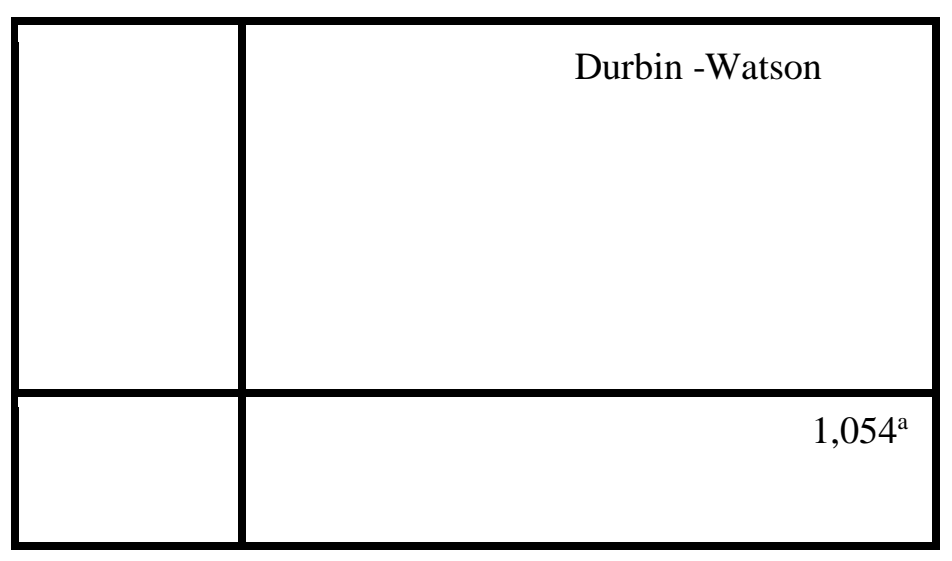

a. Predictors: (Constant), FASPER, Size

b. Dependent variable: CTR

Kesimpulan dari tabel diatas adalah jika nilai DW yang diperoleh sebesar 1,054 dan nilai ini dibandingkan dengan nilai signifikansi 5\%. Yang mana hal ini berdasar kepada syarat yang dimiliki oleh DW antara -2 sampai dengan +2 , yang menyebabkan tidak terjadinya autokorelasi.

\section{Koefisien Determinasi}

\section{Model-Summary}


- A . P Jurnal Audit \& Perpajakan

Volume : 1 | Nomor 1 | November 2021 | E-ISSN : 2809-1809. | DOI: 10.47709/jap.v1n1.1203

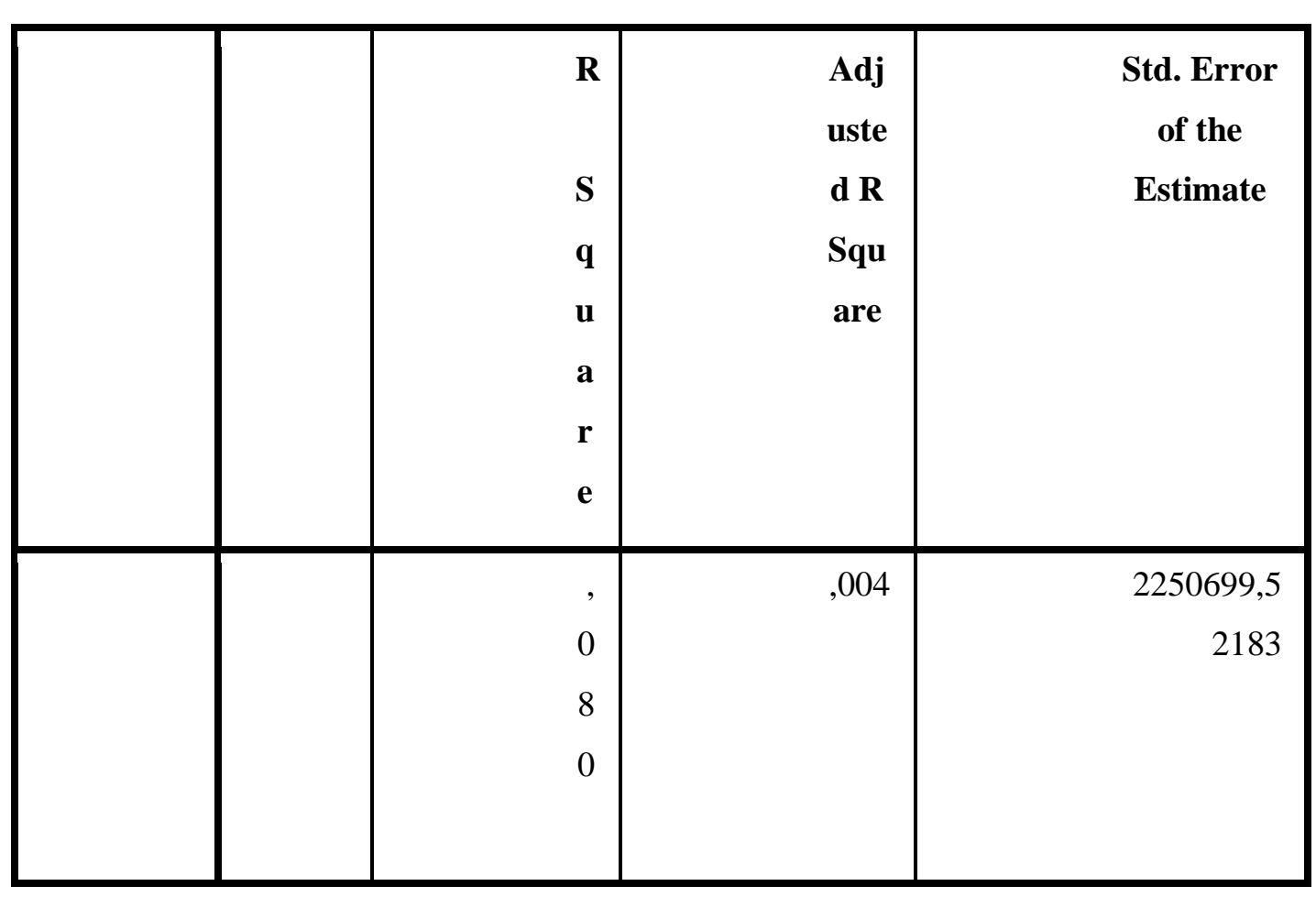

a. Predictors: (Constant), FASPER, SIZE

Dari hasil model summary diatas diperoleh nilai koefisiennya sebesar 0,080. Hal ini mempunyai arti bahwa manajemen pajak dapat diberikan penjelasan oleh fasilitas perpajakan dan ukuran perusahaan sebesar $8 \%$ secara simultan. Sedangkan sisanya yaitu $92 \%$ tidak dijelaskan pada penelitian ini.

\section{Uji F}

\begin{tabular}{|c|c|r|r|r|r|r|}
\hline \multicolumn{7}{|c|}{ ANOVA $^{\text {a }}$} \\
\hline \multirow{2}{|c|}{ Model } & $\begin{array}{c}\text { Sum } \\
\text { of } \\
\text { Squar } \\
\text { es }\end{array}$ & df & $\begin{array}{c}\text { Mean } \\
\text { Square }\end{array}$ & F & Sig. \\
\hline & $\begin{array}{c}\text { Regre } \\
\text { ssion }\end{array}$ & 17.205 & 2 & 8.603 & 3.6 & $.0211^{\text {b }}$ \\
\hline
\end{tabular}


๑ A . P Jurnal Audit \& Perpajakan

Volume : 1 | Nomor 1 | November 2021 | E-ISSN : 2809-1809. | DOI: 10.47709/jap.v1n1.1203

\begin{tabular}{|r|r|r|r|r|r|}
\hline $\begin{array}{l}\text { Resid } \\
\text { ual }\end{array}$ & 157.61 & 30 & 5.254 & & \\
\hline Total & 174.81 & 32 & & & \\
& 9 & & & & \\
\hline
\end{tabular}

a. Dependent Variable: Abs_RES

b. Predictors: (Constant), SIZE, FASPER

Berdasarkan uji F diatas, diketahui nilai $\mathrm{F}$ sebesar 3,637 dengan nilai sig 0,0211 < 0,05 sehingga dapat disimpulkan bahwa ukuran perusahaan dan fasilitas pajak memiliki pengaruh signifikan terhadap manajemen pajak.

Uji t

\section{Coefficients $^{\mathrm{a}}$}

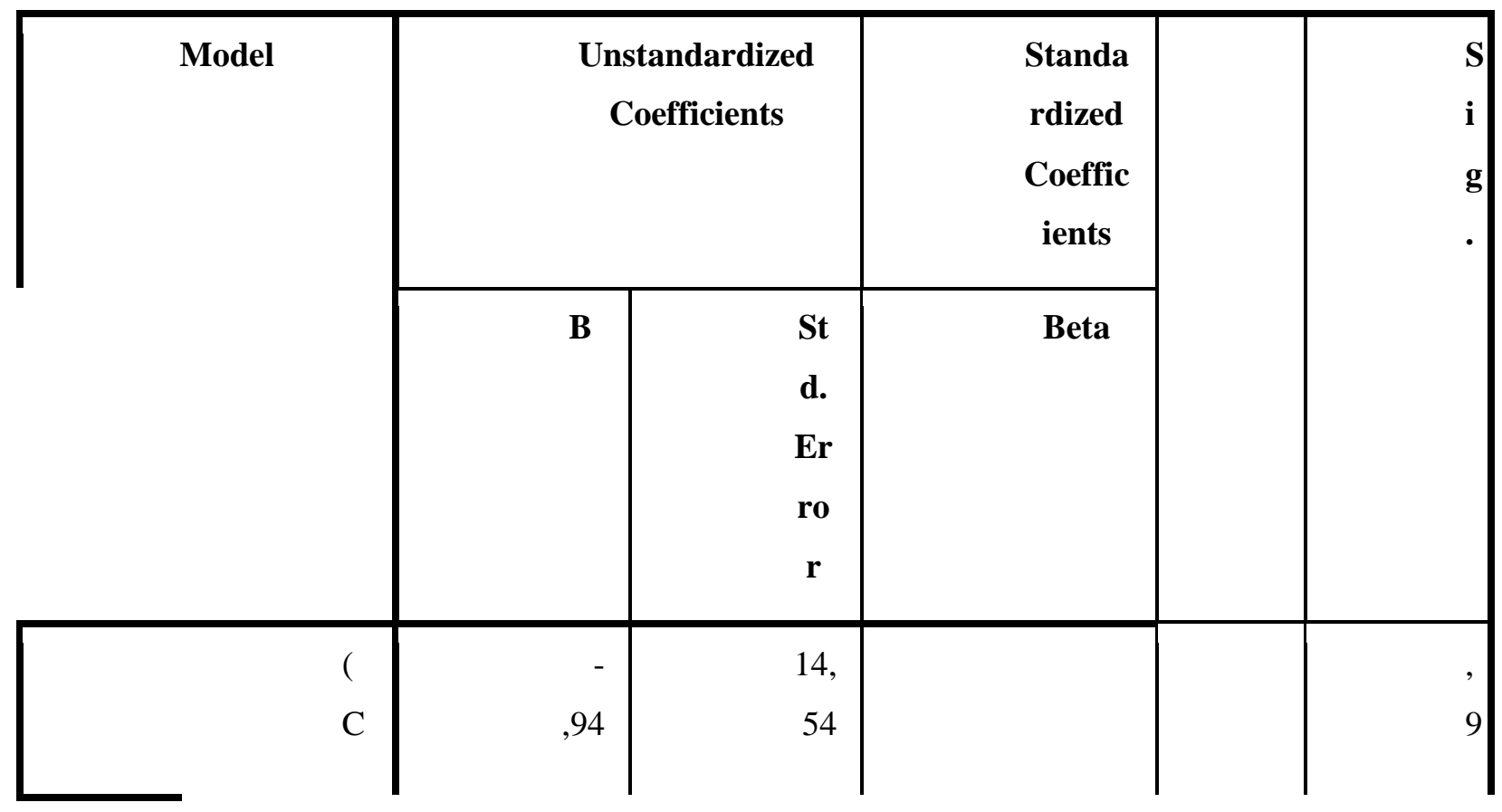


\. • P Jurnal Audit \& Perpajakan

Volume : 1 | Nomor 1 | November 2021 | E-ISSN : 2809-1809. | DOI: 10.47709/jap.v1n1.1203

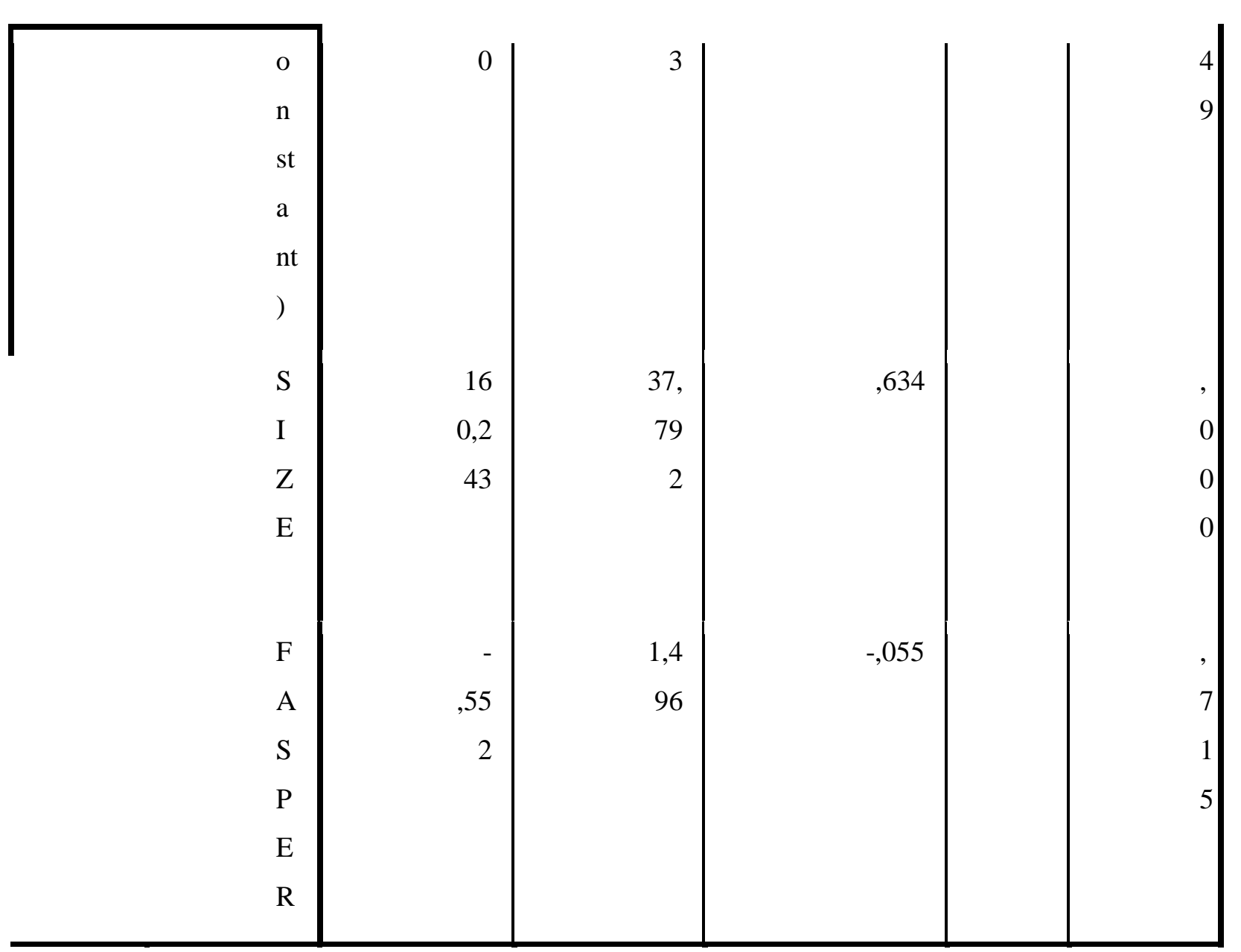

a. Dependent Variable: MANPAK

Berdasarkan hasil uji t pada tabel diatas diketahui bahwa fasilitas perpajakan memiliki nilai signifikansi sebesar 0,715>0,05 yang artinya fasilitas perpajakan tidak berpengaruh signifikan terhadap manajemen pajak dan nilai signifikansi variabel ukuran perusahaan 0,000 $<0,05$ yang artinya ukuran perusahaan memiliki pengaruh terhadap manajemen pajak.

\section{ANALISA DAN PEMBAHASAN}

\section{Pengaruh Fasilitas Perpajakan terhadap Manajemen Pajak}


\. • P Jurnal Audit \& Perpajakan

Volume : 1 | Nomor 1 | November 2021 | E-ISSN : 2809-1809. | DOI: 10.47709/jap.v1n1.1203

Berdasarkan dari hasil uji $t$, dapat menunjukkan nilai fasilitas perpajakan sebesar 0,715 lebih besar dari 0,05. Hasil ini mengartikan bahwa fasilitas pajak tidak memiliki pengaruh terhadap manajemen pajak karena perusahaan yang memperoleh fasilitas perpajakan lebih kecil dibandingkan perusahaan yang tidak memperoleh fasilitas pajak. Pada penelitian terdahulu oleh Fitri (2018) menyatakan bahwa fasilitas perpajakan tidak tidak memiliki pengaruh signifikansi terhadap manajemen pajak.

\section{Pengaruh Ukuran Perusahaan terhadap Manajemen Pajak}

Berdasarkan hasil uji $t$, dapat menunjukkan nilai signifikan ukuran perusahaan senilai 0,000 lebih kecil dari 0,05. Hasil ini mengartikan bahwa ukuran perusahaan memiliki pengaruh terhadap manajemen pajak. Sehingga hasil ini menerima hipotesis bahwa ukuran perusahaan memiliki pengaruh terhadap manajemen pajak. Hasil penelitian tersebut selaras dengan penelitian Sinaga dan Sukartha (2018), Stamatopoulos (2019) bahwa ukuran perusahaan memiliki pengaruh terhadap manajemen pajak.

\section{Pengaruh Fasilitas Perpajakan dan Ukuran Perusahaan terhadap Manajemen Pajak}

Pada penelitian ini dapat diketahui bahwa fasilitas pajak tidak memiliki pengaruh terhadap manajemen pajak dan ukuran perusahaan memiliki pengaruh signifikansi terhadap manajemen pajak. Hasil ini sesuai dengan penelitian yang dilakukan Devina (2021) perusahaan berskala besar mempunyai pengelolaan pajak lebih optimal dibanding perusahaan berskala kecil disebabkan oleh sumber daya yang dimiliki dapat dipakai guna melakukan pengelolaan pajak.

\section{Pembahasan}

\section{Pengaruh Fasilitas Perpajakan terhadap Manajemen Pajak}

Berdasarkan dari hasil uji $t$, dapat menunjukkan nilai fasilitas perpajakan sebesar 0,715 lebih besar dari 0,05. Hasil ini mengartikan bahwa fasilitas pajak tidak memiliki pengaruh terhadap manajemen pajak karena perusahaan yang memperoleh fasilitas perpajakan lebih kecil dibandingkan perusahaan yang tidak memperoleh fasilitas pajak. Pada penelitian terdahulu oleh Fitri (2018) menyatakan bahwa fasilitas perpajakan tidak tidak memiliki pengaruh signifikansi terhadap manajemen pajak.

\section{Pengaruh Ukuran Perusahaan terhadap Manajemen Pajak}


\. • P Jurnal Audit \& Perpajakan

Volume : 1 | Nomor 1 | November 2021 | E-ISSN : 2809-1809. | DOI: 10.47709/jap.v1n1.1203

Berdasarkan hasil uji $t$, dapat menunjukkan nilai signifikan ukuran perusahaan senilai 0,000 lebih kecil dari 0,05. Hasil ini mengartikan bahwa ukuran perusahaan memiliki pengaruh terhadap manajemen pajak. Sehingga hasil ini menerima hipotesis bahwa ukuran perusahaan memiliki pengaruh terhadap manajemen pajak. Hasil penelitian tersebut selaras dengan penelitian Sinaga dan Sukartha (2018), Stamatopoulos (2019) bahwa ukuran perusahaan memiliki pengaruh terhadap manajemen pajak.

\section{Pengaruh Fasilitas Perpajakan dan Ukuran Perusahaan terhadap Manajemen Pajak}

Pada penelitian ini dapat diketahui bahwa fasilitas pajak tidak memiliki pengaruh terhadap manajemen pajak dan ukuran perusahaan memiliki pengaruh signifikansi terhadap manajemen pajak. Hasil ini sesuai dengan penelitian yang dilakukan Devina (2021) perusahaan berskala besar mempunyai pengelolaan pajak lebih optimal dibanding perusahaan berskala kecil disebabkan oleh sumber daya yang dimiliki dapat dipakai guna melakukan pengelolaan pajak.

\section{Kesimpulan}

Berdasarkan hasil penelitian didapati sebagai berikut:

Secara parsial variabel fasilitas pajak tidak memiliki pengaruh terhadap manajemen pajak pada perusahaan manufaktur sub-sektor tekstil dan garmen yang terdaftar di BEI. Variabel ukuran perusahaan berpengaruh signifikansi terhadap manajemen perpajakan pada perusahaan manufaktur sub-sektor tekstil dan garmen yang terdaftar di BEI. Dan hasil uji secara simultan variabel ukuran perusahaan dan fasilitas pajak memiliki pengaruh signifikansi terhadap manajemen pajak pada perusahaan manufaktur sub-sektor tekstil dan garmen yang terdaftar di BEI.

\section{Ucapan Terima Kasih (opsional)}

\section{Referensi}

Referensi menggunakan APA CITATION STYLE $6^{\text {th }}$ Edition

Annisa, A., Taufik, T., \& Hanif, R. A. (2017). Pengaruh Return on Asset, Leverage, Ukuran Perusahaan dan Koneksi Politik Terhadap Penghindaran Pajak (Studi Empiris Pada 


\section{- 1 - Jurnal Audit \& Perpajakan \\ Volume : 1 | Nomor 1 | November 2021 | E-ISSN : 2809-1809. | DOI: 10.47709/jap.v1n1.1203}

Perusahaan Manufaktur yang Terdaftar di BEI Periode Tahun 2012-2015). Universitas Riau. Doctoral Dissertation.

Clarasati, F. N. (2019). Pengaruh Tax Planning, Tunneling Incentive, Intangible Asets, Leverage and Profitabilitas Terhadap Keputusan Perusahaan Melakukan Transfer Pricing. Universitas Islam Negeri Sunan Ampel Surabaya. Doctoral Dissertation.

Devina, M., \& Pradipta, A. (2021). Pengaruh Fasilitas Perpajakan, Return On Asset, Leverage, Ukuran Perusahaan, Dan Intensitas Aset Tetap Terhadap Manajemen Pajak. E-Jurnal Akuntansi Tsm, 1(1), 25-32.

Fitriana, E., \& Isthika, W. (2021). Pengaruh Size, Profitabilitas, Leverage and Capital Intensity Ratio Terhadap Manajemen Pajak. Jurnal Riset Akuntansi (Juara), 11(1), 18-33.

Madya, E. (2021). Pengaruh Return on Asset, Leverage, dan Ukuran Perusahaan Terhadap Tax Avoidance. YUME: Journal of Management, 4(2).

Nurfitriani, F., \& Hidayat, A. (2021). Pengaruh Intensitas Aset Tetap, Tingkat Hutang dan Kompensasi Dewan Komisaris dan Direksi Terhadap Manajemen Pajak. Iqtishaduna: Jurnal Ilmiah Ekonomi Kita, 10(1), 1-18.

Putri, Z. A. N., \& Mahpudin, E. (2021). Pengaruh Profitabilitas, Leverage, dan Ukuran Perusahaan Terhadap Manajemen Pajak Pada Perusahaan Properti dan Real Estate Tahun 2016-2020. Yume: Journal Of Management, 4(3). 
Reinaldo, R., Zirman, Z., \& Rusli, R. (2017). Pengaruh Leverage, Ukuran Perusahaan, ROA, Kepemilikan Institusional, Kompensasi Kerugian Fiskal, dan CSR Terhadap Tax Avoidance Pada Perusahaan Manufaktur Subsektor Makanan Dan Minuman Terdaftar Di BEI 2013-2015. Riau University. Doctoral Dissertation.

Saraswati, G. A. R. S., \& Sujana, I. K. (2017). Pengaruh Pajak, Mekanisme Bonus, dan Tunneling Incentive pada Indikasi Melakukan Transfer Pricing. E-Jurnal Akuntansi Universitas Udayana, 19(2), 1000-1029.

Sari, E. P., \& Mubarok, A. (2018, February). Pengaruh Profitabilitas, Pajak dan Debt Covenant Terhadap Transfer Pricing (Studi Empiris Perusahaan Manufaktur Terdaftar di BEI Tahun 2012-2016). In Proseding Seminar Nasional Akuntansi (Vol. 1, No. 1).

Tania, C., \& Kurniawan, B. (2019). Pajak, Tunneling Incentive, Mekanisme Bonus dan Keputusan Transfer Pricing (Studi Empiris pada Perusahaan Manufaktur yang terdaftar di Bursa Efek Indonesia Tahun 2014-2017). TECHNOBIZ: International Journal of Business, 2(2), 82-86.

Tiwa, E. M., Saerang, D. P., \& Tirayoh, V. (2017). Pengaruh Pajak dan Kepemilikan Asing Terhadap Penerapan Transfer Pricing Pada Perusahaan Manufaktur Yang Terdaftar Di BEI Tahun 2013-2015. Jurnal EMBA: Jurnal Riset Ekonomi, Manajemen, Bisnis Dan Akuntansi, 5(2). 